\title{
Leucite content of selected dental porcelains
}

\author{
Peter W. Piché, William J. O'Brien,* Carole L. Groh, and Kenneth M. Boenke \\ Department of Biologic and Materials Sciences, School of Dentistry, The University of Michigan, Ann Arbor, \\ Michigan 48109-1078
}

Leucite is a major crystalline component of dental porcelains. The presence of tetragonal leucite in dental porcelains increases their coefficients of thermal expansion due to its high coefficient of thermal expansion $\left(20-25 \times 10^{-6} /{ }^{\circ} \mathrm{C}\right)$. This is particularly useful for those porcelains designed for bonding to precious metals and nickel alloys. The purpose of this study was to determine the leucite content of selected commercial dental porcelains in relation to their coefficient of thermal expansion values. The weight fraction of leucite was determined with quantitative $x$-ray diffraction using copper as an internal standard. Coefficient of thermal expansion values were determined using a thermal dilatometric analyzer. Five commercial body porcelains were studied. Leucite was not detected in samples of Vitadur $\mathrm{N}$ and Duceram LFC. An ANOVA showed that there was a significant difference in the weight fraction of leucite for Silhouette, Ceramco II, and Optec HSP porcelains. Linear regression revealed a correlation $(R=0.91)$ between weight fraction of leucite and the coefficient of thermal expansion for those samples containing leucite. Duceram LFC, which is recommended by the manufacturer for use with metals and leucite-containing porcelains, had no detectable leucite although the coefficient of thermal expansion was found to be $13.2 \pm 0.4 \times 10^{-6} /{ }^{\circ} \mathrm{C}$ at $25-472^{\circ} \mathrm{C}$. A low glass transition temperature contributed to the high average coefficient of thermal expansion value. (c) 1994 John Wiley \& Sons, Inc.

\section{INTRODUCTION}

All-porcelain crowns have been used in dentistry since the 1890 s to restore teeth. The coefficient of thermal expansion of these feldspathic porcelains is around $9-10 \times 10^{-6} /{ }^{\circ} \mathrm{C}$, but their tensile strengths were low $(35 \mathrm{MPa})$. Therefore, these porcelains often fractured. ${ }^{1}$

In 1962, porcelain formulations suitable for fusing to alloy substructures were developed. ${ }^{2,3}$ This type of restoration was made possible by the development of a porcelain enamel with a coefficient of thermal expansion slightly lower than that of precious metals and nickel alloys $\left(14.1-15.7 \times 10^{-6} /{ }^{\circ} \mathrm{C}\right) .{ }^{4}$ $\mathrm{X}$-ray diffraction studies indicated that tetragonal leucite $\left(\mathrm{K}_{2} \mathrm{O} \cdot \mathrm{Al}_{2} \mathrm{O}_{3} \cdot 4 \mathrm{SiO}_{2}\right)$ was a major crystalline component of dental porcelains. ${ }^{5-9}$ The presence of tetragonal leucite in dental porcelains increases their coefficient of thermal expansion

*To whom correspondence should be addressed.

Presented at the International Association for Dental Research, Chicago, Illinois, March 1993. due to its high coefficient of thermal expansion $\left(20-25 \times 10^{-6} /{ }^{\circ} \mathrm{C}\right) .{ }^{10}$ The amount of leucite in these porcelains can be effected by a variety of thermal treatments. Multiple firing, ${ }^{11,12}$ isothermal heat treatments, ${ }^{11}$ and cooling rate ${ }^{13}$ have been shown to be capable of altering the leucite content of dental porcelains.

The thermal expansion of dental porcelains has been studied by Fairhurst et al. ${ }^{14}$ Whitlock et al., ${ }^{4}$ Mackert et al., ${ }^{15,16}$ and Mackert and Evans. ${ }^{17}$ Various studies have described the changes in thermal expansion of these porcelains as the result of multiple firing. ${ }^{4,14,17}$ A relationship between thermal expansion and leucite content has been described by Mackert and Evans. ${ }^{12}$

Recently, new ceramics have been introduced for the construction of all-ceramic jacket crowns. Examples of core reinforced crowns include alumia, ${ }^{18}$ highexpansion magnesia, ${ }^{19}$ and high-content leucite. ${ }^{20}$

The purpose of this study was to determine the weight fraction of leucite in five commercial dental porcelains in relation to their coefficient of thermal expansion values. The porcelains studied include those 


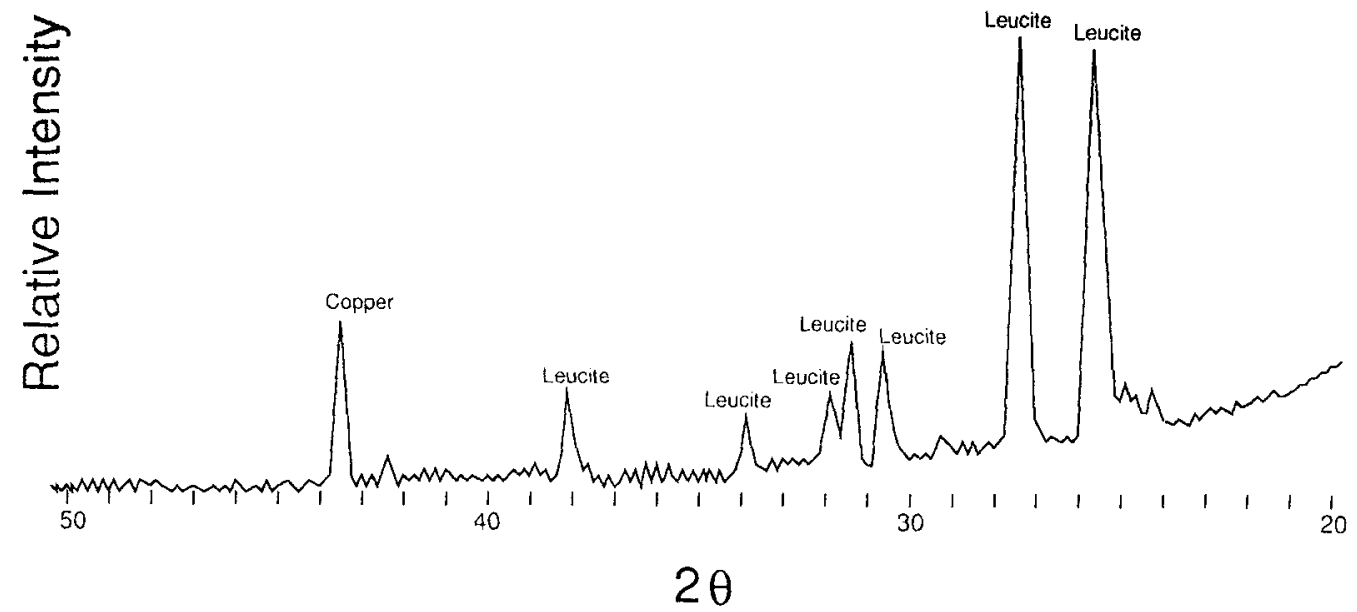

Figure 1. An x-ray diffraction pattern of leucite with the copper standard.

designed for porcelain-fused-to-metal and all-ceramic jacket crown techniques.

\section{EXPERIMENTAL PROCEDURES}

The weight fraction of leucite of commercial dental porcelains was determined using quantitative $x$-ray diffraction with copper as the internal standard. In the method used, a diffraction line from the phase being determined is compared with a line from a standard substance mixed with the sample in known proportions. ${ }^{21}$ Four calibration standards were prepared with leucite (Ward's Natural Science Establishment, Inc., Rochester, NY) and a silica glass. The leucite had been ground and sieved to a particle size of $<37 \mu \mathrm{m}$. The weight fraction of leucite in these standards were $0.30,0.50,0.70$, and 1.00 , and the balance was the silica glass. Nine parts of each standard were mixed with one part of copper (Electrolytic Dust; Fisher Scientific, Pittsburgh, PA) prior to $x$-ray analysis. Six $x$-ray diffraction patterns were recorded over the $2 \theta$ range of $20-50^{\circ}$, at the rate of $1^{\circ} 2 \theta / \mathrm{min}$, for each of the standards using an x-ray diffractometer (Model XRG-3000; Philips Electronic Instruments, Mahwah, $\mathrm{NJ}$ ). In this $2 \theta$ range, the tetragonal leucite peak at $27.27^{\circ}(d=0.327 \mathrm{~nm})$ and a copper peak at $43.2^{\circ}(d=0.209 \mathrm{~nm})$ were suitable for quantitative analysis (Fig. 1). The calibration curve (Fig. 2) was generated by plotting the ratio of the peak intensities $\left(I_{L} / I_{C}\right)$ as a function of the weight fraction of leucite $\left(\mathrm{W}_{\mathrm{L}}\right)$. The peak height method of measuring

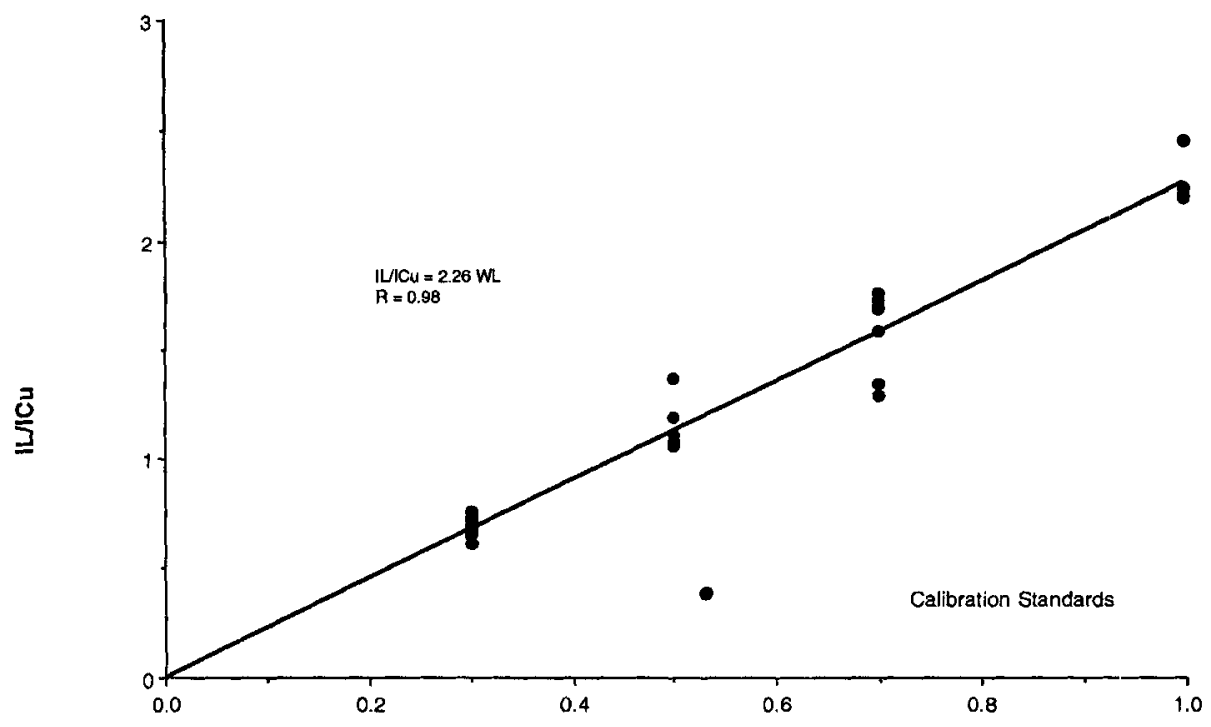

Weight Fraction Leucite (WL)

Figure 2. The calibration curve generated by plotting the ratio of the peak intensities $\left(\mathrm{I}_{\mathrm{L}} / \mathrm{I}_{\mathrm{C}}\right)$ as a function of the weight fraction of leucite $\left(W_{L}\right)$. 
TABLE I

Weight Fraction of Leucite and the Coefficients of Thermal Expansion for Five Commercial Dental Porcelains

\begin{tabular}{lc|cc}
\hline \multicolumn{1}{c}{ Porcelain } & Weight Fraction of Leucite (SD) & CE $\left(\times 10^{6} /{ }^{\circ} \mathrm{C}\right)$ & Temp Range $\left({ }^{\circ} \mathrm{C}\right)$ \\
\hline Vitadur N & None detected & $7.1(0.1)$ & $25-500$ \\
Duceram LFC & None detected & $13.2(0.4)^{\dagger}$ & $25-472$ \\
Silhouette & $0.17(0.01)$ & $14.0(0.2)$ & $25-500$ \\
Ceramco II & $0.25(0.02)$ & $13.4(0.1)$ & $25-500$ \\
Optec HSP & $0.41(0.02)$ & $19.2(0.6)$ & $25-500$ \\
\hline
\end{tabular}

*X-ray measurements were run on the unfired porcelain powders.

${ }^{\dagger}$ Duceram LFC measurement did not proceed beyond $472^{\circ} \mathrm{C}$, the softening temperature for this material.

Groups joined by vertical lines are not significantly different using Scheffe F-test at the $95 \%$ confidence level.

maximum intensities is permissible when the shape of the diffraction lines is found to be essentially constant from sample to sample. As long as all patterns are made under identical experimental conditions, there is a constant proportionality between maximum and integrated intensities, and the measurement of maximum intensities gives satisfactory results. ${ }^{21}$

The weight fraction of leucite in five commercial dental porcelains (Vitadur N, C4 Dentine, Vident, Inc, Baldwin Park, CA; Duceram LFC, A1 Dentine, Degussa Corp., South Plainfield, NJ; Silhouette, A2 Dentine, Leach and Dillon, Mansfield, MA; Ceramco II, A2 Body, Ceramco, Inc., Burlington, NJ; and Optec HSP, A2 Body, Jeneric/Pentron, Wallingford, CT) was determined using the calibration curve generated above. Nine parts of the unfired powder for each commercial porcelain were mixed with one part of copper prior to x-ray analysis. The mixture was placed in a powder sample holder for the diffractometer. Six x-ray diffraction patterns were recorded over the $2 \theta$ range of $20-50^{\circ}$, at the rate of $1^{\circ}$ $2 \theta / \mathrm{min}$, for each of the batches. The ratio of the peak intensities $\left(\mathrm{I}_{\mathrm{L}}\right.$ at $27.27^{\circ} / \mathrm{I}_{\mathrm{C}}$ at $\left.43.2^{\circ}\right)$ were plotted on the calibration curve and the weight fraction of leucite $\left(\mathrm{W}_{\mathrm{L}}\right)$ was determined. A one-way analysis of variance was performed to determine the affect of brand on weight fraction of leucite. Pairwise comparisons were run with simultaneous confidence intervals.

The samples for the determination of thermal expansion were prepared by compressing the powder in a metal mold to provide rectangular bars $6 \mathrm{~mm} \times 6 \mathrm{~mm} \times 51 \mathrm{~mm}$. The bars were fired according to the schedule recommended by the manufacturers of the various porcelains. The thermal dialtometric analyzer (Model TDA-H1-MP6; Harrop Laboratories, Columbus, $\mathrm{OH}$ ) was calibrated on the cooling curve using an alumina standard. The coefficient of thermal expansion values for each material were determined in replicate using the cooling curves of the second and third heating cycles at $25-500^{\circ} \mathrm{C}$ with a heating and cooling rate of $4^{\circ} \mathrm{C} / \mathrm{min}$. Since the softening temperature of Duceram LFC was below $500^{\circ} \mathrm{C}$, its coefficient of thermal expansion was determined on the heating curve for the second and third heating cycles. A linear regression was performed to determine the relationship of the coefficient of thermal expansion values to the weight fraction of leucite.

\section{RESULTS}

The calibration curve for the leucite, shown in Figure 2, demonstrated a high correlation $(R=0.98$, $P<.0001)$ between the ratio of the peak intensities $\left(\mathrm{I}_{\mathrm{L}} / \mathrm{I}_{\mathrm{C}}\right)$ and the weight fraction of leucite $\left(\mathrm{W}_{\mathrm{L}}\right)$.

Results for the weight fraction of leucite in five commercial dental porcelains are presented in Table I. Leucite was not detected in samples of Vitadur $\mathrm{N}$ and Duceram LFC (Fig. 3). The weight fraction of leucite in Silhouette, Ceramco II, and Optec HSP was $0.17 \pm 0.01,0.25 \pm 0.02$, and $0.41 \pm 0.02$, respectively (Figs. 4-6). An ANOVA showed that there was a significant difference in weight fraction of leucite in these three porcelains.

Results for the coefficient of thermal expansion value determinations of the five commercial dental porcelains are given in Table I. The coefficients of thermal expansion at $25-500^{\circ} \mathrm{C}$ of Vitadur N, Silhouette, Ceramco II, and Optec HSP were $7.1 \pm 0.1$, $14.0 \pm 0.2,13.4 \pm 0.1$, and $19.2 \pm 0.6 \times 10^{-6} /{ }^{\circ} \mathrm{C}$, respectively. A typical thermal expansion curve for

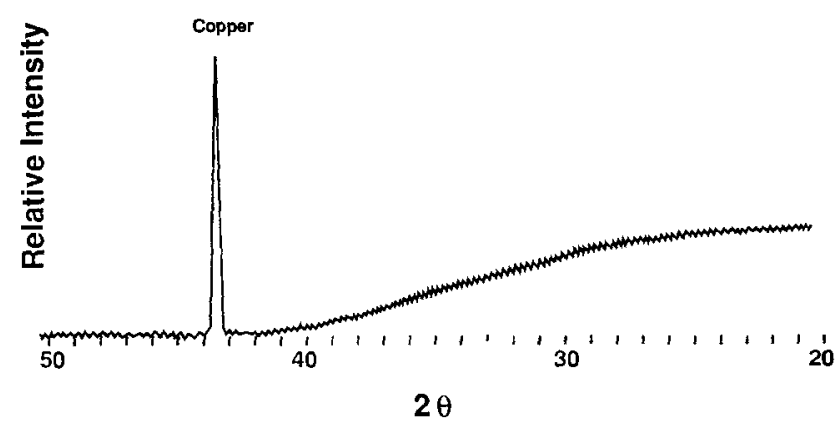

Figure 3. An x-ray diffraction pattern of Duceram LFC with the copper standard. No leucite peaks were observed 


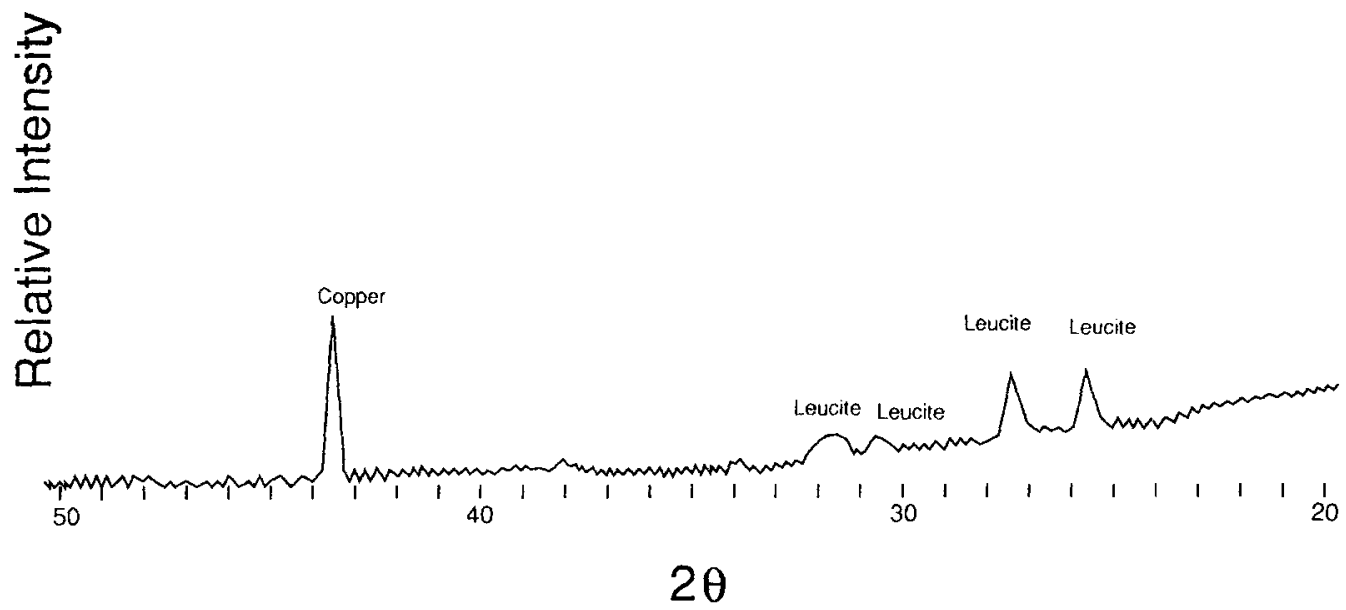

Figure 4. An $x$-ray diffraction pattern of Silhouette with the copper standard. The ratio of the peak intensities $\left(\mathrm{I}_{\mathrm{L}}\right.$ at $27.27^{\circ} / \mathrm{I}_{\mathrm{C}}$ at $\left.43.2^{\circ}\right)$ was $0.40 \pm 0.02$, and the weight fraction of leucite was $0.17 \pm 0.01$.

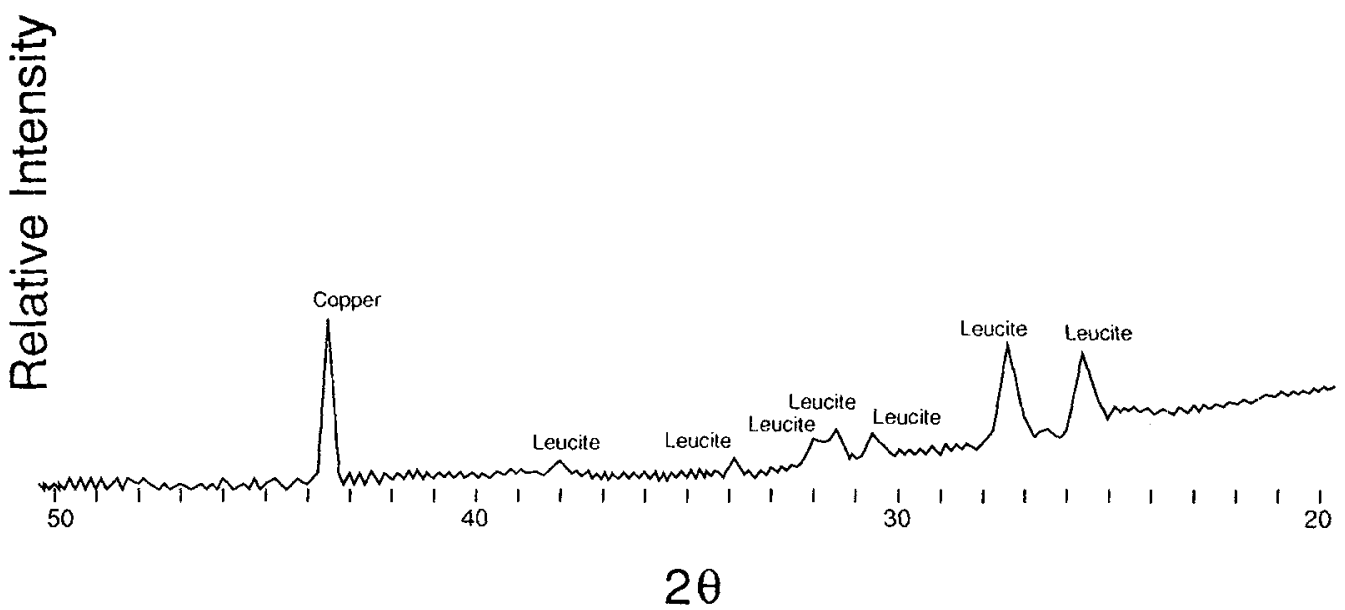

Figure 5. An x-ray diffraction pattern of Ceramco II with the copper standard. The ratio of the peak intensities $\left(\mathrm{I}_{\mathrm{L}}\right.$ at $27.27^{\circ} / \mathrm{I}_{\mathrm{C}}$ at $\left.43.2^{\circ}\right)$ was $0.57 \pm 0.04$, and the weight fraction of leucite was $0.25 \pm 0.02$.

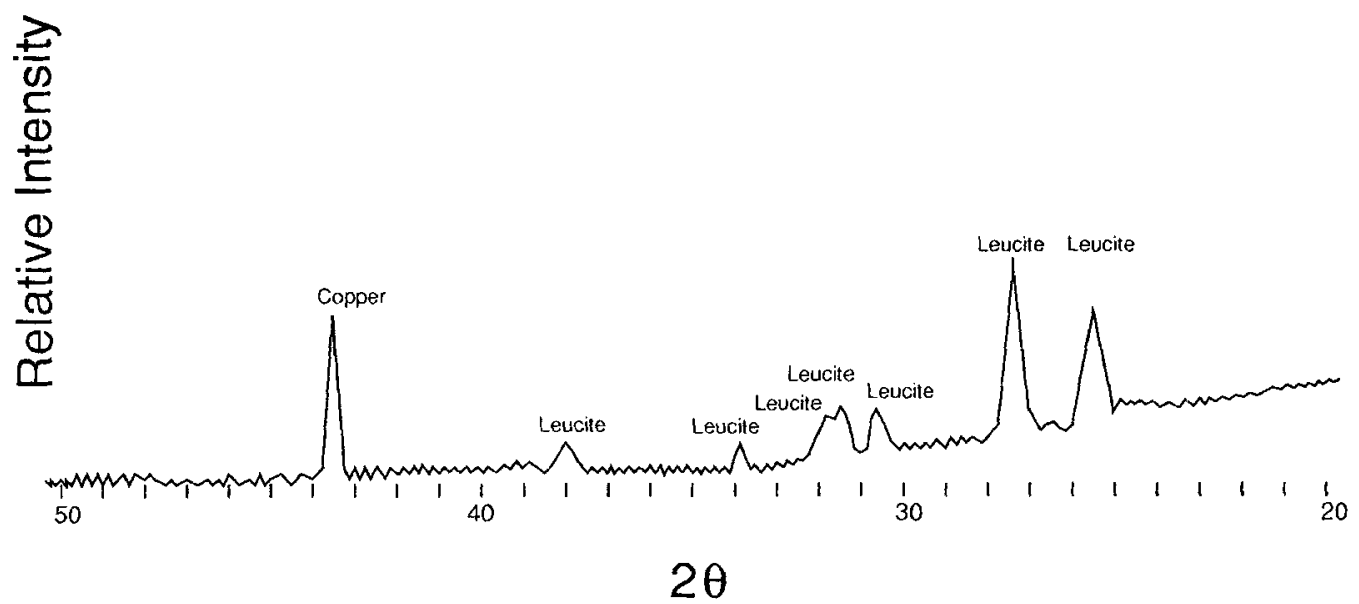

Figure 6. An x-ray diffraction pattern of Optec HSP with the copper standard. The ratio of the peak intensities $\left(I_{L}\right.$ at $27.27^{\circ} / I_{C}$ at $43.2^{\circ}$ ) was $0.92 \pm 0.05$, and the weight fraction of leucite was $0.41 \pm 0.02$. 


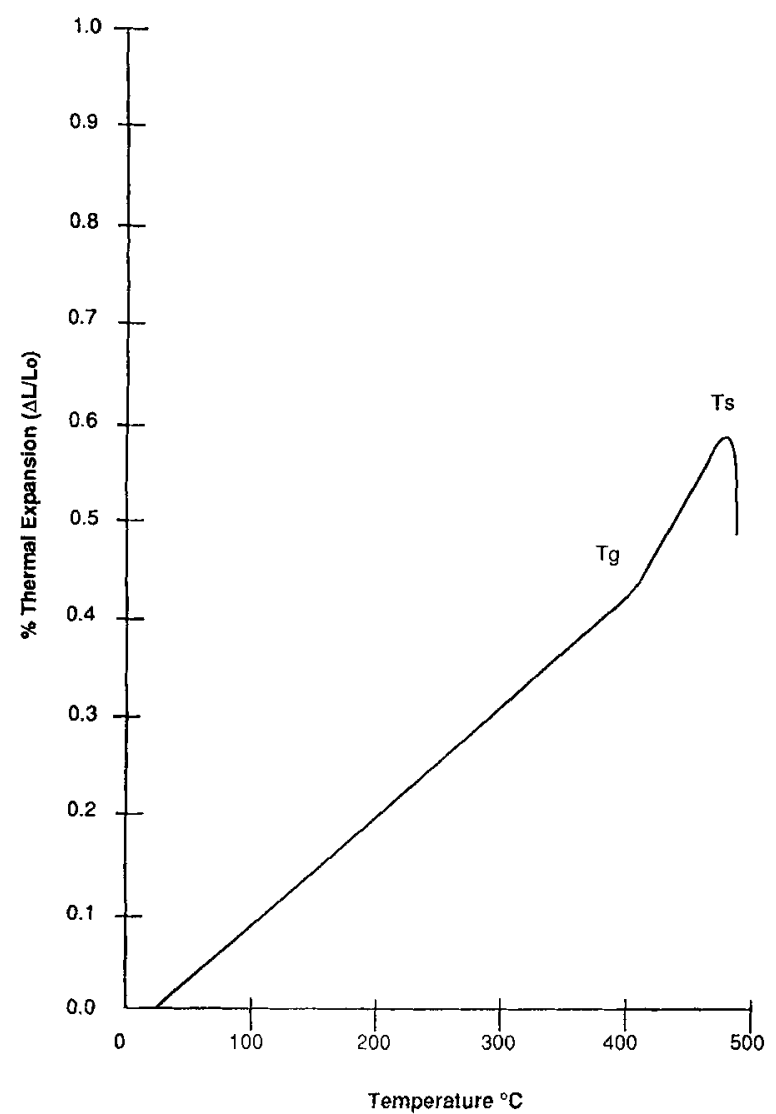

Figure 7. A typical thermal expansion curve for Duceram LFC. The glass transition temperature $\left(T_{g}\right)$ was determined to be $410 \pm 6^{\circ} \mathrm{C}$. The softening temperature $\left(\mathrm{T}_{\mathrm{s}}\right)$ was determined to be $472 \pm 5^{\circ} \mathrm{C}$. The coefficient of thermal expansion $\left(25-T_{g}\right)$ was $11.2 \pm 0.1 \times 10^{-6} /{ }^{\circ} \mathrm{C}$, and the coefficient of thermal expansion $\left(\mathrm{T}_{g}-\mathrm{T}_{\mathrm{s}}\right)$ was $25.7 \pm 2.9 \times 10^{-6} /{ }^{\circ} \mathrm{C}$.

Duceram LFC is shown in Figure 7. Since the softening temperature of Duceram LFC was below $500^{\circ} \mathrm{C}$, the coefficient of thermal expansion was measured at $25-472^{\circ} \mathrm{C}$ and was found to be $13.2 \pm 0.4 \times 10^{-6} /{ }^{\circ} \mathrm{C}$. The rapid rise in the thermal expansion between the glass transition temperature and the softening temperature accounted for some of the high coefficient of thermal expansion of Duceram LFC. However, the relatively high coefficient of thermal expansion between room temperature and the glass transition temperature was still very high $\left(11.2 \pm 0.1 \times 10^{-6} /{ }^{\circ} \mathrm{C}\right)$ for a non-leucite porcelain.

Linear regression revealed a correlation $(R=0.91)$ between weight fraction of leucite and the coefficient of thermal expansion for the leucite-containing samples (Fig. 8).

No peaks were detected in samples of Vitadur $\mathrm{N}$ and Duceram LFC dentine porcelains indicating that there were no significant quantities of crystalline substances that were detectable above the background. A sample of Ducera Porcelain Jacket Crown Material Jacket Opaquer (Opaque Material A3, Degussa Corp.) was scanned, and peaks for $\mathrm{Al}_{2} \mathrm{O}_{3}, \mathrm{SnO}_{2}$, and leucite were observed. A sample of Vitadur $\mathrm{N}$ Core (A2; Vident, Inc.) was scanned, and peaks for $\mathrm{Al}_{2} \mathrm{O}_{3}$ were observed. However, these materials were not quantified since one of the alumina peaks coincides with the copper peak at $43.2^{\circ}$. Therefore, although the core/opaque porcelains for Duceram and Vitadur $\mathrm{N}$ contain $\mathrm{Al}_{2} \mathrm{O}_{3}$, and sometimes $\mathrm{SnO}_{2}$ and leucite, these compounds do not appear in the dentine porcelains for these brands.

\section{DISCUSSION}

Vitadur $\mathrm{N}$ is an example of an aluminous core porcelain. Although alumina was detected in the core material, it was not detected in the dentine porcelain. The measured coefficient of thermal expansion for the dentine porcelain is consistent with the coefficient of thermal expansion for pure alumina $\left(7.1 \times 10^{-6} /{ }^{\circ} \mathrm{C}\right) .{ }^{22}$

Typical coefficients of thermal expansions for commercial PFM body porcelains are 12.7 to $16.2 \times$ $10^{-6} /{ }^{\circ} \mathrm{C} .{ }^{5}$ Therefore, in addition to having a significantly higher weight fraction of leucite, Optec HSP also has a higher coefficient of thermal expansion than other commercial dental porcelains. Optec HSP is a system designed to fabricate all-ceramic restorations and would not be compatible with precious metals and nickel alloys having coefficients of thermal expansion in the range of $14.1-15.7 \times 10^{-6} /{ }^{\circ} \mathrm{C}$.

Duceram LFC, which is recommended by the manufacturer for use with metals and leucitecontaining porcelains, had no detectable leucite although the average coefficient of thermal expansion was found to be $13.2 \pm 0.4 \times 10^{-6} /{ }^{\circ} \mathrm{C}$ up to $472^{\circ} \mathrm{C}$. The absence of crystalline leucite in this new product is consistent with the microstructures published by the manufacturer. ${ }^{23}$ After firing $x$-ray diffraction patterns of the Duceram LFC did not reveal the formation of any detectable crystalline phases. It is interesting to note that Duceram showed a coefficient of thermal expansion higher than feldspathic porcelains in the absence of leucite. A low glass transition temperature contributed to the high average coefficient of thermal expansion value.

\section{CONCLUSIONS}

This study demonstrated that there was a correlation $(R=0.91)$ between the weight fraction of leucite of the unfired powders for three commercial leucitecontaining dental porcelains and the coefficient of thermal expansion. This finding is consistent with those of Mackert and Evans, ${ }^{12}$ who found that there is a correlation between the leucite content of fired porcelains and the coefficient of thermal expansion. 


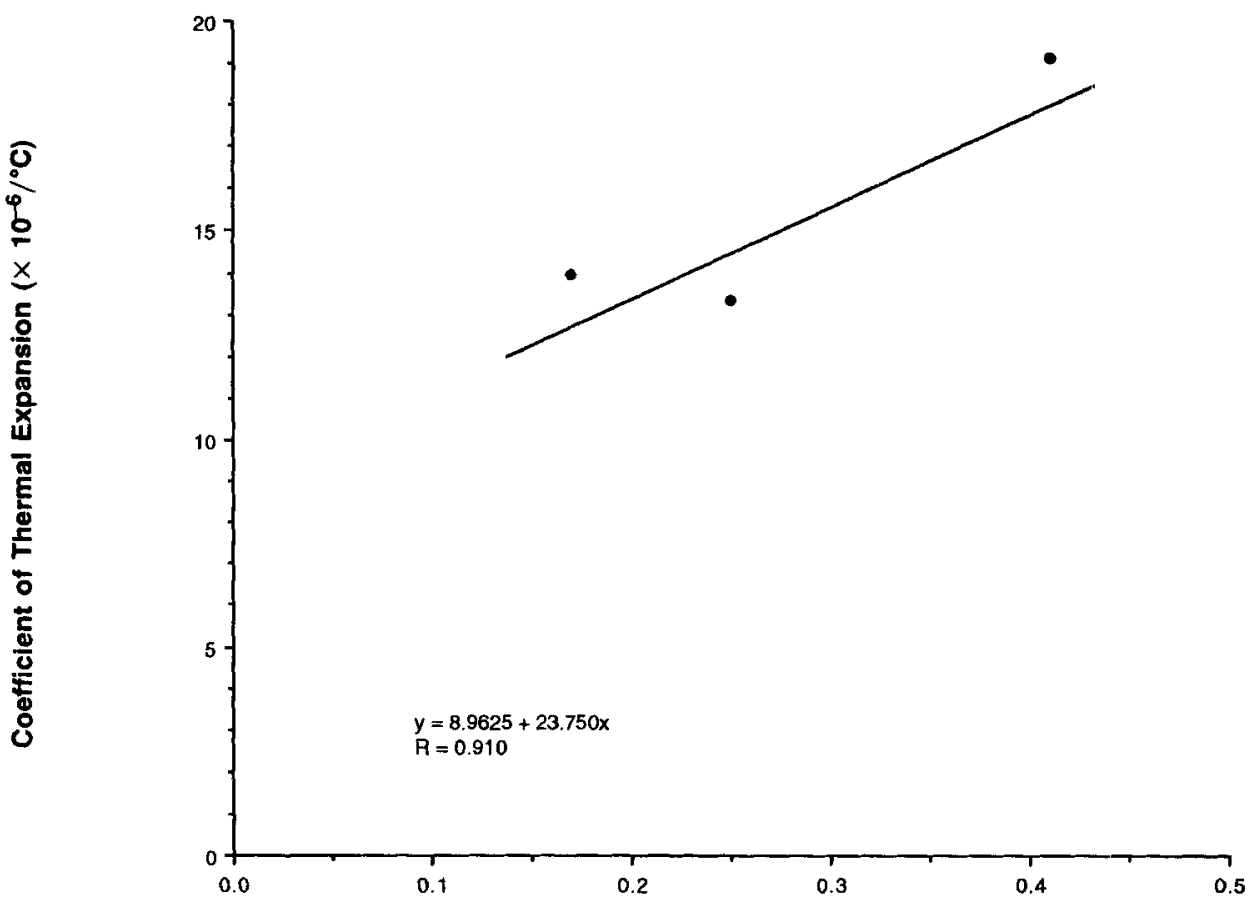

Weight Fraction Leucite (WL)

Figure 8. The correlation between coefficient of thermal expansion and weight fraction of leucite for three leucite-containing commercial body porcelains.

Duceram LFC showed a coefficient of thermal expansion higher than feldspathic porcelains in the absence of leucite. A low glass transition temperature contributed to the high average coefficient of thermal expansion value.

This study was supported by Grant DE-09296 from the National Institute of Dental Research, National Institutes of Health, Bethesda, Maryland.

\section{References}

1. W. J. O'Brien, "Dental porcelains," in Encyclopedia of Materials Science and Engineering, M.B. Bever (ed.), Pergamon Press, Oxford, 1986, pp. 1099-1102.

2. M. Weinstein, S. Katz, and A.B. Weinstein, "Fused porcelain-to-metal teeth," U.S. Patent no. 3,052,982 (September 11, 1962).

3. M. Weinstein and A.B. Weinstein, "Porcelain covered metal-reinforced teeth," U.S. Patent no. 3,052,983 (September 11, 1962).

4. R. P. Whitlock, J. A. Tesk, G.E.O. Widera, A. Holmes, and E.E. Parry, "Consideration of some factors influencing compatibility of dental porcelains and alloys. Part I. Thermophysicial properties," in Proceedings of the 4th International Precious Metals Conference, Pergamon Press Canada, Willowdale, Ontario, 1981, pp. 273-282.

5. W.J. O'Brien and G. Ryge, "Relation between molecular force calculations and observed strengths of enamel-metal interfaces," J. Am. Ceram. Soc., 47, 5-8 (1964).

6. I. Poggioli and J. Tuleff, "Utilisation de la diffractometrie des rayons $x$ pour l'etude mineralogique des porcelaines opaques ceramo-metalliques," Rev. Fr. Odontostomatol., 17, 205-222 (1970).

7. J. R. Mackert, Jr., M. B. Butts, G. M. Beaudreau, C. W. Fairhurst, and R.H. Beauchamp, "Ultrathinning dental porcelain for transmitted light microscopy," J. Dent. Res., 64, 1170-1175 (1985).

8. M. M. Barreiro, O. Riesgo, and E. E. Vicente, "Phase identification in dental porcelains for ceramometallic restorations," Dent. Mater., 5, 51-57 (1989).

9. M. Schmid, J. Fischer, M. Salk, and J. Strub, "Mikrogefüge leucit-verstärkter glaskeramiken," Schweiz. Monatsschr. Zahnmed., 102, 1046-1053 (1992).

10. M. A. Rouf, L. Hermansson, and R. Carlsson, "Crystallization of glasses in the primary phase field of leucite in the $\mathrm{K}_{2} \mathrm{O} \cdot \mathrm{Al}_{2} \mathrm{O}_{3} \cdot \mathrm{SiO}_{2}$ system," Trans. $J$. Brit. Ceram. Soc, 77, 36-39 (1978).

11. J.R. Mackert, Ir., and A.L. Evans, "Quantitative $\mathrm{X}$-ray diffraction determination of leucite thermal instability in dental porcelains," J. Am. Ceram. Soc., 74, 450-453 (1991).

12. J.R. Mackert, Jr., and A. L. Evans, "Multiple firing effect on leucite content of dental porcelains and correlation with thermal expansion," J. Dent. Res., 71, 238, Abst. no. 1060 (1992).

13. J.R. Mackert, Jr., and A. L. Evans, "Effect of cooling rate on leucite volume fraction in dental porcelains," J. Dent. Res., 70, 137-139 (1991).

14. C.W. Fairhurst, K.J. Anusavice, D.T. Hashinger, R.D. Ringle, and S.W. Twiggs, "Thermal expansion of dental alloys and porcelains," J. Biomed. Mater. Res., 14, 435-446 (1980).

15. J.R. Mackert, Jr., M. B. Butts, and C.W. Fairhurst, "The effect of the leucite transformation on dental porcelain expansion," Dent. Mater., 2, 32-36 (1986).

16. J.R. Mackert, Jr., M.B. Butts, R. Morena, and C.W. Fairhurst, "Phase changes in a leucite-containing 
dental porcelain frit," J. Am. Ceram. Soc., 69, C69-C72 (1986).

17. J.R. Mackert, Jr., and A. L. Evans, "Multiple firing effect on thermal expansion of four dental porcelains," J. Dent. Res., 71, 238, Abst. no. 1059 (1992).

18. J.W. McLean and H. Hughes, "The reinforcement of dental porcelain with ceramic oxides," Br. Dent. J., 119, 251-267 (1965).

19. W.J. O'Brien, "High expansion feldspar porcelain and magnesia core materials," in Proceedings of Conference on Recent Developments in Dental Ceramics, W. J. O'Brien and R. G. Craig (eds.), American Ceramic Society, Columbus, 1985, pp. 10-18.
20. S. Katz, "High strength feldspathic dental porcelains containing crystalline leucite," U.S. Patent no. 4,798,536 (January 17,1989 ).

21. B.D. Cullity, Elements of X-ray Diffraction, 2 nd ed., Addison-Wesley, Reading, MA, 1978, pp. 407-420.

22. M.F. Yan, K. Niwa, H. M. O'Bryan, Jr., and W.S. Young, Advances in Ceramics, Vol. 26, American Ceramic Society, Westerville, $\mathrm{OH}, 1989$, pp. 87-105.

23. O. Komma, Hydrothermal Dental Ceramic Systems, Ducera Dental GmbH, Rosbach, Germany, 1993.

Received August 31, 1993

Accepted December 3, 1993 